\title{
An Examination Into Self-Efficacy, Metacognition and Academic Performance of Pre-Service ELT Students: Prediction and Difference
}

\author{
Yrd. Doç. Dr. Bülent ALCI* \\ Yıldız Teknik Üniversitesi, Eğitim Fakültesi, Eğitim Bilimleri Bölümü, Davutpaşa, İstanbul \\ Yrd. Doç. Dr. Gülru YÜKSEL \\ Yıldız Teknik Üniversitesi, Eğitim Fakültesi, Yabancı Diller Eğitimi Bölümü, Davutpaşa, İstanbul
}

\begin{abstract}
The aim of this study is of twofold: to examine in what degree the undergraduate ELT students' sense of self-efficacy and metacognitive awareness predict their academic performance, and to investigate the difference in self-efficacy beliefs and metacognitive awareness according to grades. The study cohorts a total of 143 students enrolled in English Language Teaching department. In the study two different instruments were used: Teachers' Sense of Self-Efficacy Scale (TSES) (Çapa, Çakıroğlu and Sarıkaya, 2005) and Metacognitive Awareness Inventory (MAI) (Schraw and Dennison, 1994). The correlation analysis suggested relation between * Sorumlu Yazar. Tel: +90 5056707647 E-posta: bulent_alci@hotmail.com

(C) 2012 Kalem Eğitim ve Sağlık Hizmetleri Vakfı. Bütün Hakları Saklıdır. ISSN: 2146-5606
\end{abstract}


self-efficacy, metacognition and academic success. Yet, the regression analysis showed that only metacognitive awareness predicts academic performance. ANOVA analysis displayed statistically significant differences in self-efficacy and metacognitive awareness scores between groups.

Keywords: Self-efficacy; Teacher's self-efficacy; Metacognitive awareness; Academic performance; Prediction.

\title{
İngilizce Öğretmenliği Lisans Öğrencilerinin Özyeterlik ve Bilişüstü Algılarının Farklılaşması ve Akademik Performanslarını Yordaması
}

\begin{abstract}
Özet
$\mathrm{Bu}$ çalışmanın amacı ELT lisans öğrencilerinin öz yeterlik ve bilişüstü farkındalıklarının akademik performanslarını ne derece yordadığının ve sınıflara göre özyeterlik inançları ve bilişüstü farkındalıktaki değişimin incelenmesidir. Çalışma İngilizce Öğretmenliği Bölümü'nde öğrenim gören 143 öğrenci üzerinde gerçekleştirilmiştir. Araştırmada Çapa, Çakıroğlu ve Sarıkaya (2005) tarafından geliştirilen Öğretmen Öz Yeterlik Ölçeği ile Schraw ve Dennison (1994) tarafından geliştirilen Bilişüstü Farkındalık Ölçeği kullanılmıştır. Uygulanan korelasyon analizi; özyeterlik, bilişüstü ve akademik başarının ilişkili olduğunu göstermiş, fakat sonrasındaki regresyon analizi, akademik performansı yordayan değişkenin yalnızca bilişüstü farkındalık olduğu sonucunu vermiştir. Yapılan ANOVA çalışması ise özyeterlik ve bilişüstü farkındalık puanlarının gruplar arasında anlamlı bir farklılaşma gösterdiğini ortaya koymuştur.
\end{abstract}

Anahtar kelimeler: Öz yeterlik; Bilişüstü; Akademik performans; Yordama. 


\section{Introduction}

Researchers in the field of educational psychology have investigated a number of variables such as goals, self-esteem, self-efficacy, motivation, learning strategies, metacognition and test anxiety in their relationship to academic performance as these variables influence learning and performance. Recently, among these variables self-efficacy and metacognition are the most foregrounded variables in the educational field. Previous research has indicated relationship between metacognition and self-efficacy. For example, Kanfer and Ackerman (1989) found that people with strong self-efficacy were more likely to use metacognitive strategies when working on a task and they performed better than those with weak self-efficacy. Similarly, Bouffard-Bouchard, Parent and Larivee (1991) found that students with strong self-efficacy engaged in more metacognitive skills and had better performance scores than students with weak self-efficacy. Bandura and Wood (1989) also found that selfefficacy influenced performance directly and indirectly through its effects on analytical strategies, which suggests a mediating effect of metacognition in the relationship between self-efficacy and performance. More recently, Coutinho (2007) in his study examining relationships among self-efficacy, metacognition and performance found that metacognition is a predictor of self-efficacy, and that self-efficacy is a predictor of performance. Thus, in this study two variables that have been of particular interest to researchers are self-efficacy and metacognition.

The present study seeks to examine self-efficacy beliefs and metacognitive awareness in relation to academic success. Academic success in 
this research refers to academic performance which is assessed by Grade Point Average (GPA). GPA is cumulated across academic subject areas and over semesters, and provides a fairly robust measure of success in university. The first variable in this study is self-efficacy beliefs. Selfefficacy is one key aspect of social-cognitive theory (Bandura, 1997). In his unifying theory of behavior change, Bandura hypothesized that expectations of self-efficacy determine whether instrumental actions will be initiated, how much effort will be expended, and how long it will be sustained in the face of obstacles and failures. The second variable in this study is metacognition which is described as "knowledge and cognition about cognitive phenomena” (Flavell, 1979, p.906). It refers to higherorder mental processes involved in learning that includes making plans for learning, using appropriate skills and strategies to solve a problem, making estimates of performance and calibrating the extent of learning (Dunslosky and Thiede, 1998).

\section{Self-efficacy}

According to Bandura's (1986) social cognitive theory, individuals control their thoughts, feelings and actions via a self-system they possess. This self-system reserves one's cognitive and affective structures and plays an important role in providing reference mechanisms and a set of sub-functions for perceiving, regulating, and evaluating behavior. The self-system with its self-regulatory function enables individuals to alter their environments and influence their own actions. In such a system the beliefs that people have about themselves become key elements in the exercise of control and personal agency. The beliefs that individuals hold 
about their abilities and about the outcome of their efforts powerfully influence the ways they behave (Pajares, 1996).

In social cognitive theory, there is a reciprocal relationship between the individual and environment. Individuals, interpreting the results of their performance attainments, inform and alter their environments and their self-beliefs. Their beliefs, in turn, inform and alter their subsequent performances. As a result, since personal agency is socially rooted and operates within socio-cultural influences, individuals are viewed both as products and as producers of their own environments and of their social systems. In this system, individuals evaluate and alter their own thinking and behavior via a form of thought known as self-reflection. Because of its function, self-reflection becomes the most important capacity unique to human-beings (Bandura, 1986). The self-evaluations include perceptions of self-efficacy, that is, "beliefs in one's capabilities to organize and execute the courses of action required to manage prospective situations" (Bandura, 1997, p.2). One's self-efficacy beliefs influence his/her thought patterns and emotional reactions. While low self-efficacy fosters stress and depression, high self-efficacy helps to create feelings of serenity in approaching difficult tasks and activities. Self-efficacy beliefs, hence, become strong determinants and predictors of the level of accomplishment that individuals finally attain.

The construct of self-efficacy has been tested in various disciplines and received support from a growing body of findings from different fields, such as phobias (Bandura, 1983), depression (Davis and Yates, 1982), social skills (Moe and Zeiss, 1982), life quality (Molt and Snook, 
2008), smoking behavior (Garcia, Schmitz and Doerfler, 1990), pain control (Keefe, Lefebvre, Maixner, Salleyan and Caldwell, 1997; Manning and Wright, 1983) and assertiveness (Lee, 1984). During the past decade, it has also received increasing attention in educational research (Pintrich and Schunk, 1995). In order to understand the role of self-beliefs in academic settings, researchers have investigated the relationship between beliefs and academic performance, and the relationship among the beliefs themselves (Pajares, 1996).

Self-efficacy beliefs, different from other expectancy beliefs, are sensitive to contextual factors, and hence judgments of self-efficacy are more task and domain specific (Pajares, 1996).Thus, to increase accuracy of prediction, self-efficacy beliefs are suggested to be assessed at the optimal level of specificity that corresponds to the criterial task being assessed and the domain of functioning being analyzed (Bandura, 1986; Pajares, 1996). Bearing this advice in mind, as the participants of the study were teacher trainees, the researchers in this study investigated teacher’s self-efficacy.

\section{Teacher's Self-efficacy}

Teachers' actions and behaviors are related to their beliefs, perceptions, assumptions and motivational levels (Chacón, 2005). Teachers' beliefs in their abilities to instruct students and influence student performance are very strong indicators of instructional effectiveness (Bandura, 1997). One of the important beliefs considered to be significantly effective in students and teachers outcomes is teachers' feelings of efficacy (Chacón, 2005). Teachers' sense of efficacy can potentially influence 
both the kind of environment that they create and the instructional practices introduced in the classroom (Bandura, 1997). Teachers' efficacy beliefs has been shown to be related to variables such as student motivation and achievement (Moore and Esselman, 1992), school effectiveness (Hoy and Woolfolk, 1993), teachers' adoption of innovations (L.S. Fuchs, D. Fuchs and Bishop, 1992), teachers' classroom management strategies (Woolfolk, Rosoff and Hoy, 1990), time allotted to teaching certain subjects and teachers' referrals of students to special education (Soodak and Podell, 1993).

Bandura's theory of self-efficacy suggests that efficacy may be most malleable early in learning. The findings of the previous studies indicate that the development of teacher efficacy beliefs is widely influenced by the experiences during student teaching and the induction year, and once they are established, they appear to be somewhat resistant to change (Hoy, 2000). There is some evidence that some aspects of efficacy increase during student teaching while other dimensions may decline (Hoy and Woolfolk, 1990). This suggests that the optimism of young teachers may be somewhat tarnished when confronted with the realities of the teaching task, and that input during initial training has a different impact on the student teacher (Hoy, 2000). If this is the case the preservice years could be critical to the long-term development of teacher efficacy. Studies across teacher preparation programs and across the first several years in the field could begin to map the development of efficacy beliefs and could assess the impact of different teacher preparation programs and practices on efficacy. One purpose of this study was to inves- 
tigate the difference, if there is any, in efficacy across early years of training.

\section{Metacognition}

The concept of metacognition, once developed in the field of developmental research, is now widely used in various areas of psychology (Schneider, 2008). Over the past twenty years although various attempts have been made to conceptualize, the concept “metacognition” has usually been broadly defined as any knowledge or cognitive activity that takes as its object, or regulates any aspect of any cognitive activity (Flavell, P.H. Miller and S. A. Miller, 1993). According to this conceptualization, metacognition refers to people's knowledge of their own informationprocessing skills, and of strategies for coping with such tasks. It also includes skills related to monitoring and self-regulation of one's own cognitive activities (Schneider, 2008). Metacognition refers to awareness and monitoring of one's thoughts and task performance, or more simply, thinking about your thinking (Flavell, 1979). It refers to higher-order mental processes involved in learning such as planning for learning, using appropriate skills and strategies to solve a problem, making estimates of performance, and calibrating the extent of learning (Dunslosky and Thiede, 1998).

Metacognition is considered as one of the key concepts in learning and is found to be a strong predictor of academic success (Dunning, Johnson, Ehrlinger and Kruger, 2003; Kruger and Dunning, 1999). Students with good metacognition demonstrate good academic performance compared to their peers with poor metacognition (Coutinho, 2007). Re- 
search findings suggest that individual differences exist in metacognition and people with poor metacognition are deemed "incompetent" as they perform inadequately relative to their peers (Kruger and Dunning, 1999). Metacognition enables students to be strategic in their learning (Everson and Tobias, 1998).

The implications of the above mentioned studies drive the purpose of this study to investigate the relationships among self-efficacy, metacognition, and academic performance in pre-service ELT students.

\section{Method}

The aim of this study is of twofold: to examine in what degree the undergraduate ELT students' sense of self-efficacy and metacognitive awareness predict their academic performance, and to investigate the difference in self-efficacy beliefs and metacognitive awareness according to grades. The following research questions were addressed in the study;

(1) In what degree do the undergraduate ELT students' sense of selfefficacy and metacognitive awareness predict their academic performance?

(2) Are there any difference in teacher self-efficacy beliefs and metacognitive awareness according to grades?

\section{Participants}

A total of 143 subjects participated in the study (98 female, 45 male). All the participants were undergraduate students enrolled in Eng- 
lish Language Teaching department at Yıldız Technical University, Turkey. The distribution of the participants according to the years was as follows: 32 first year, 47 second year, 32 third year and 32 fourth year students. Ages ranged from 18 years to $22(\mathrm{M}=20.84, \mathrm{SD}=2.38)$.

\section{Procedure}

This study employed descriptive methodology. At the beginning of the spring semester of 2010-2011 academic year, participants were asked to complete two questionnaires: Teachers' Sense of Self-Efficacy Scale (Çapa, Çakıroğlu and Sarıkaya, 2005) and Metacognitive Awareness Inventory (MAI) (Schraw adn Dennison, 1994). After explaining the aim of the study, both questionnaires were distributed to the students at the same time within the same week. The students who volunteered to participate in the study, filled in and returned the questionnaires to the researchers. Students who did not want to participate were not given any questionnaires. For each grade it took students 20 minutes to fill in the questionnaire. In order to collect data related to students' GPAs, the researchers applied to the Students' Office at the end of the same semester. After the approval of the Students' Office, the IT Office sent the GPAs of the students who participated in the study.

\section{Instruments}

\section{Turkish teachers' sense of self-efficacy scale (TTSES)}

The first questionnaire used in the study was the Turkish version of Teachers' Sense of Self-Efficacy Scale which was developed by Tschannen-Moran and Woolfolk Hoy (2001) and adapted into Turkish by Çapa, Çakıroğlu and Sarıkaya (2005). This instrument comprises 24-item likert 
scale. Students responded to each item on a 9-point scale ranging from strongly disagree (1) to strongly agree (9). Some example items from the questionnaire are; "How much can you do to get through to the most difficult students?, How much can you do to help your students think critically?, How much can you do to control disruptive behavior in the classroom?”. Scores for each item on the TTSES were summed to obtain a composite score for self-efficacy. For the whole scale, the reliability of efficacy scores was 0.93 .

\section{Metacognitive awareness inventory (MAI)}

The second questionnaire was the 52-item Metacognitive Awareness Inventory (MAI) (Schraw and Dennison, 1994). This is a long, comprehensive scale assessing various facets of metacognition. Participants responded to each item on a 7-point scale ranging from strongly disagree (1) to strongly agree (7). Example items in the questionnaire are; "I ask myself periodically if I am meeting my goals, I consider several alternatives to a problem before I answer, I try to use strategies that have worked in the past”. Scores for each item on the MAI were summed to obtain a composite score for MAI metacognition. Since the 7-point version of the scale has not been translated into Turkish and since the students are from the English Language Teaching Department, the researchers preferred using the original English version of the scale. The relative reliability coefficient, Cronbach's alpha value for the scale was found as 0.96 .

\section{Data analysis}

The data collected was quantitavely analyzed. The analysis involved following statistical procedures: (1) descriptive statistics, includ- 
ing frequencies, means, and standard deviations were computed to summarize the data; (2) Pearson correlations analysis were conducted to examine the relationships between the teacher's self-efficacy beliefs, metacognitive awareness and GPAs; (3) Regression regression analysis was done to find whether teacher's self-efficacy and metacognitive awareness predict academic performance, and (4) One-Way ANOVA was conducted to find the differences, if any, in teacher's self-efficacy and metacognition according to grades.

\section{Results}

The means and standard deviations for teacher's self-efficacy and metacognitive awareness scores, and GPA are given in Table 1.

Table 1. Descriptive statistics for teachers' self-efficacy, metacognition and GPA

\begin{tabular}{lcccc}
\hline & Min. & Max. & Mean & Std. Deviation \\
\hline Self-efficacy & 75 & 210 & 162.29 & 22.45 \\
\hline Metacognition & 205 & 357 & 285.81 & 36.76 \\
\hline GPA & 1.72 & 3.65 & 2.61 & 0.44 \\
\hline
\end{tabular}

Relations between the variables were first examined with Pearson correlations between variables. The correlation analysis was computed in order to examine the relational patterns of the variables of interest. Table 2 presents the correlations between all variables in the study. We found statistically significant correlation between teacher's self-efficacy and metacognition $(r=0.64, \mathrm{p}<0.01)$. The correlations between teacher's selfefficacy and GPA, and metacognition and GPA were also statistically 
significant ( $r=0.16, \mathrm{p}<0.05$, and $\mathrm{r}=0.30 \mathrm{p}<0.01$, respectively).

Table 2. Correlations between teachers' self-efficacy and metacognition scores and GPA

\begin{tabular}{|c|c|c|c|c|}
\hline & & $\begin{array}{l}\text { Self-efficacy } \\
\qquad(n=143)\end{array}$ & $\begin{array}{c}\text { Metacognition } \\
\quad(n=143)\end{array}$ & $\begin{array}{c}\text { GPA } \\
(n=143)\end{array}$ \\
\hline \multirow[t]{2}{*}{ Self-efficacy } & $\begin{array}{l}\text { Pearson } \\
\text { Correlation }\end{array}$ & 1 & $0.64^{* *}$ & $0.16^{*}$ \\
\hline & Sig. (2-tailed) & & 0.00 & 0.05 \\
\hline \multirow[t]{2}{*}{ Metacognition } & $\begin{array}{l}\text { Pearson } \\
\text { Correlation }\end{array}$ & $0.64^{* *}$ & 1 & $0.30^{* *}$ \\
\hline & Sig. (2-tailed) & 0.00 & & 0.00 \\
\hline \multirow[t]{2}{*}{ GPA } & $\begin{array}{l}\text { Pearson } \\
\text { Correlation }\end{array}$ & $0.16^{*}$ & $0.30^{* *}$ & 1 \\
\hline & Sig. (2-tailed) & 0.05 & 0.00 & \\
\hline
\end{tabular}

** Correlation is significant at the 0.01 level (2-tailed).

*. Correlation is significant at the 0.05 level (2-tailed).

As a second step regression analysis was conducted to determine the extent to which GPA can be predicted from teacher's self-efficacy and metacognition. The results of the analysis are given in Table 3. As displayed in the table metacognition significantly predicted GPA ( $\mathrm{p}=0.002)$, however, teacher's self-efficacy was not a significant predictor of GPA ( $\mathrm{p}=0.672)$. 
Table 3. Regression analysis results for teachers' self-efficacy, metacognition and GPA

\begin{tabular}{|c|c|c|c|c|c|c|}
\hline \multirow[b]{2}{*}{ Model } & \multicolumn{2}{|c|}{$\begin{array}{c}\text { Unstandardized } \\
\text { Coefficients }\end{array}$} & \multicolumn{2}{|c|}{$\begin{array}{c}\text { Standardized } \\
\text { Coefficients }\end{array}$} & \multirow[b]{2}{*}{$\mathbf{t}$} & \multirow[b]{2}{*}{ Sig. } \\
\hline & B & $\begin{array}{l}\text { Std. } \\
\text { Error }\end{array}$ & \multicolumn{2}{|c|}{ Beta } & & \\
\hline (Constant) & 1.636 & 0.300 & \multirow{2}{*}{\multicolumn{2}{|c|}{-0045}} & 5.456 & 0.00 \\
\hline Self-efficacy & 0.000 & 0.002 & & & -0.42 & 0.67 \\
\hline Metacognition & 0.004 & 0.001 & \multicolumn{2}{|c|}{0.326} & 3.103 & 0.00 \\
\hline \multicolumn{7}{|c|}{$\begin{array}{l}\text { a. Predictors: (Constant), Self- efficacy, Metacognition } \\
\text { b. Dependent Variable: GPA }\end{array}$} \\
\hline \multicolumn{7}{|c|}{ In order to find the differences in teacher's self-efficacy and meta } \\
\hline \multirow{2}{*}{\multicolumn{7}{|c|}{$\begin{array}{l}\text { cognition according to grades, One-Way ANOVA analysis was conduct } \\
\text { ed. The analysis revealed significant differences both in teacher's self } \\
\text { efficacy and metacognition (Table } 4 \text { ). }\end{array}$}} \\
\hline & & & & & & \\
\hline \multicolumn{7}{|c|}{$\begin{array}{l}\text { Table 4. ANOVA results for self-efficacy and metacognition accordin } \\
\text { to the grades }\end{array}$} \\
\hline & & $\begin{array}{l}\text { Sum of } \\
\text { Squares }\end{array}$ & df & $\begin{array}{l}\text { Mean } \\
\text { Square }\end{array}$ & $\mathbf{F}$ & Sig. \\
\hline \multirow{3}{*}{ Self-efficacy } & $\begin{array}{l}\text { Between } \\
\text { Groups }\end{array}$ & 6272.01 & 3 & 2090.67 & 4.44 & 0.005 \\
\hline & $\begin{array}{l}\text { Within } \\
\text { Groups }\end{array}$ & 65357.64 & 139 & 470.19 & & \\
\hline & Total & 71629.66 & 142 & & & \\
\hline \multirow{3}{*}{ Metacognition } & $\begin{array}{l}\text { Between } \\
\text { Groups }\end{array}$ & 16473.55 & 3 & 5491.18 & 4.35 & 0.006 \\
\hline & $\begin{array}{l}\text { Within } \\
\text { Groups }\end{array}$ & 175463.71 & 139 & 1262.32 & & \\
\hline & Total & 191937.27 & 142 & & & \\
\hline
\end{tabular}


As can be seen in Table 4, both teacher's self-efficacy and metacognitive awareness displayed significant differences according to grades ( $\mathrm{p}=0.005$ and $\mathrm{p}=0.006$, respectively). In order to find among which grades this difference is resulting from we performed Scheffe test as a post hoc test. The results of the post hoc analysis are given in Table 5.

Table 5. Scheffe test results for teachers' self-efficacy and metacognition

\begin{tabular}{|c|c|c|c|c|c|c|c|}
\hline \multirow{2}{*}{$\begin{array}{l}\text { Dependent } \\
\text { Variable }\end{array}$} & \multirow{2}{*}{$\begin{array}{c}\text { (I) } \\
\text { grade }\end{array}$} & \multirow{2}{*}{$\begin{array}{c}(\mathrm{J}) \\
\text { grade }\end{array}$} & \multirow{2}{*}{$\begin{array}{c}\text { Mean } \\
\text { Difference } \\
\text { (I-J) }\end{array}$} & \multirow{2}{*}{$\begin{array}{l}\text { Std. } \\
\text { Error }\end{array}$} & \multirow{2}{*}{ Sig. } & \multicolumn{2}{|c|}{$\begin{array}{c}\text { 95\% Confidence } \\
\text { Interval } \\
\end{array}$} \\
\hline & & & & & & $\begin{array}{l}\text { Lower } \\
\text { Bound }\end{array}$ & $\begin{array}{l}\text { Upper } \\
\text { Bound }\end{array}$ \\
\hline \multirow{12}{*}{ Self-efficacy } & \multirow{3}{*}{1} & 2 & -10.01 & 4.96 & 0.259 & -24.08 & 4.04 \\
\hline & & 3 & $-15.87^{*}$ & 5.42 & 0.039 & -31.21 & -0.53 \\
\hline & & 4 & $-18.06^{*}$ & 5.42 & 0.013 & -33.40 & -2.72 \\
\hline & \multirow{3}{*}{2} & 1 & 10.01 & 4.96 & 0.259 & -4.04 & 24.08 \\
\hline & & 3 & -5.85 & 4.96 & 0.709 & -19.92 & 8.20 \\
\hline & & 4 & -8.04 & 4.96 & 0.457 & -22.10 & 6.02 \\
\hline & \multirow{3}{*}{3} & 1 & $15.87^{*}$ & 5.42 & 0.039 & 0.53 & 31.21 \\
\hline & & 2 & 5.85 & 4.96 & 0.709 & -8.20 & 19.92 \\
\hline & & 4 & -2.18 & 5.42 & 0.983 & -17.52 & 13.15 \\
\hline & \multirow{3}{*}{4} & 1 & $18.06^{*}$ & 5.42 & 0.013 & 2.72 & 33.40 \\
\hline & & 2 & 8.04 & 4.96 & 0.457 & -6.02 & 22.10 \\
\hline & & 3 & 2.18 & 5.42 & 0.983 & -13.15 & 17.52 \\
\hline \multirow{5}{*}{ Metacognition } & \multirow{3}{*}{1} & 2 & $-23.37^{*}$ & 8.14 & 0.045 & -46.42 & -0.33 \\
\hline & & 3 & -18.00 & 8.88 & 0.255 & -43.13 & 7.13 \\
\hline & & 4 & $-30.21^{*}$ & 8.88 & 0.011 & -55.35 & -5.08 \\
\hline & \multirow{2}{*}{2} & 1 & $23.37^{*}$ & 8.14 & 0.045 & 0.33 & 46.42 \\
\hline & & 3 & 5.37 & 8.14 & 0.932 & -17.66 & 28.42 \\
\hline
\end{tabular}




\begin{tabular}{ccccccc} 
& 4 & -6.83 & 8.14 & 0.872 & -29.88 & 16.20 \\
\hline \multirow{3}{*}{3} & 1 & 18.00 & 8.88 & 0.255 & -7.13 & 43.13 \\
\cline { 2 - 7 } & 2 & -5.37 & 8.14 & 0.932 & -28.42 & 17.66 \\
\cline { 2 - 7 } & 4 & -12.21 & 8.88 & 0.596 & -37.35 & 12.91 \\
\hline \multirow{3}{*}{4} & 1 & $30.21^{*}$ & 8.88 & 0.011 & 5.08 & 55.35 \\
\cline { 2 - 7 } & 2 & 6.83 & 8.14 & 0.872 & -16.20 & 29.88 \\
\cline { 2 - 7 } & 3 & 12.21 & 8.88 & 0.596 & -12.91 & 37.35 \\
\hline
\end{tabular}

*. The mean difference is significant at the 0.05 level

Post hoc analyses using the Scheffé post hoc criterion for significance indicated that the average teacher's self-efficacy scores of the $1^{\text {st }}$ year students was significantly lower than that of the $3^{\text {rd }}$ and $4^{\text {th }}$ year students. As for the metacognition, the results showed that $2^{\text {nd }}$ and $4^{\text {th }}$ graders' metacognitive awareness scores were higher than that of the $1^{\text {st }}$ graders $(\mathrm{p}<0.05)$.

\section{Discussion}

The present study was conducted to investigate the relation between teacher's self-efficacy, metacognition and performance of preservice ELT students, and to examine any difference across grades. There were significant correlations among performance, teacher's self-efficacy and metacognition. The correlation between teacher's self-efficacy and metacognition suggest that these two variables are dependent of each other. In other words, students high in teacher's self-efficacy beliefs are likely to have high metacognitive awareness. These correlations were in line with the findings of the previous studies (Multon, Brown and Lent, 1991; Coutinho, 2007; Krugger and Dunning, 1999). The correlation 
between metacognition and GPA was stronger than the correlation between teacher's self-efficacy and GPA. Despite the existing correlations between the variables, the regression analysis has yielded an interesting result. Unlike previous studies, teacher's self-efficacy was not a significant predictor of performance, but metacognition was a significant predictor of performance. Previous research has shown a partially mediated model for metacognition in the relationship between self-efficacy and performance (e.g., Bouffard-Bouchard, Parent and Larivee, 1991; Kanfer and Ackerman, 1989). This result might be because of the self-efficacy being tested. Different from the previous studies we did not test general self-efficacy, but rather teacher's self-efficacy. In the case of general selfefficacy the results might have been different.

Another finding of this study is that both teacher's self-efficacy and metacognition increase by time. Third and fourth year students held stronger teacher self-efficacy beliefs and had a higher level of metacognitive awareness. This suggests that teacher preparation program positively influenced our students. The increase in teacher's self-efficacy supports Hoy and Woolfolk (1990) that some aspects of self-efficacy change during student teaching. Similarly, the increase in metacognition indicates that learners change their strategies throughout their education, and thus strategy training might positively influence their performance (e.g., Diseth and Martinsen, 2003; Downing, 2009; Yip and Chung, 2005) 


\section{Conclusion}

Previous studies in self-efficacy and metacognition has already shown that both self-efficacy and metacognition are essential to successful learning. The results of these studies emphasize the importance of teacher's self-efficacy and metacognition on performance. The most successful students are those with strong metacognitive skills who manage, monitor and evaluate their performance, and have confidence in their abilities to perform successfully. The findings of our study showed that both teacher's sense of self-efficacy and metacognition increase by time. This indicates that these two constructs are closely related to experience gained by time. The increase found in these two constructs also lends supports that promoting metacognitive awareness and the teaching of metacognitive strategies enhance student performance. In the process of teacher education if the teacher trainers design tasks to help the student teachers increase their self-efficacy and metacognitive awareness, this increase might have positive affect on their academic performance.

While the sample in this study involved all the students enrolled in the department, there is no assumption that the participants of this study are representative of all foreign language education department students in the country or of foreign language teacher education students elsewhere. The study should be repeated with larger samples from different backgrounds. The changes can also be traced in a longitudinal study. 


\section{References}

Bandura, A. (1983). Self-efficacy determinants of anticipated fears and calamities. Journal of Personality and Social Psychology, 45, 464-469.

Bandura, A. (1986). Social foundations of thought and action: A social cognitive theory. Englewood Cliffs, NJ: Prentice Hall.

Bandura, A. (1997). Self-efficacy: The exercise of control. New York: Freeman.

Bandura, A., \& Wood, R. (1989). Effect of perceived controllability and performance standards on self-regulation of complex decision making. Journal of Personality and Social Psychology, 56(5), 805-814.

Bouffard-Bouchard, T., Parent, S., \& Larivèe, S. (1991). Influence of self-efficacy on self-regulation and performance among junior and senior high-school aged students. International Journal of Behavioral Development, 14, 153-164.

Chacón, C. (2005). Teachers' perceived efficacy among English as a foreign language teachers in middle schools in Venezuela. Teaching and Teacher Education, 21, 257-272. doi:10.1016/j.tate.2005.01.001

Coutinho, S. (2007). The relationship between goals, metacognition, and academic success. Educate , 7(1), 39-47.

Çapa, Y., Çakiroglu, J., \& Sarikaya, H. (2005). The development and validation of a Turkish version of teachers' sense of efficacy scale. Education and Science, 30(137), 74-81. 
Davis, F. W., \& Yates, B. T. (1982). Self-efficacy expectancies versus outcome expectancies as determinants of performance deficits and depressive affect. Cognitive Therapy and Research, 6, 2335.

Diseth, A. \& Martinsen, O. (2003) Approaches to learning, cognitive style, and motives as predictors of academic achievement. Educational Psychology, 23(2), 195-207. doi: 10.1080/01443410303225.

Downing, K. J. (2009). Self-efficacy and metacognitive development. The International Journal of Learning, 16(4), 185-199.

Dunning, D., Johnson, K., Ehrlinger, J., \& Kruger, J. (2003). Why people fail to recognize their own incompetence. Current Directions in Psychological Science, 12(3), 83-87. doi: 10.1111/14678721.01235 .

Dunslosky, J., \& Thiede, K. W. (1998). What makes people study more? An evaluation of factors that affect self-paced study. ActaPsychologica, 98, 37-56.

Everson, H. T., \& Tobias, S. (1998). The ability to estimate knowledge and performance in college: A metacognitive analysis. Instructional Science, 26, 65-79.

Flavell, J. H. (1979). Metacognition and cognitive monitoring: A new area of psychological inquiry. American Psychologist, 34, 906911.

Flavell, J. H., Miller, P. H., \& Miller, S. A. (1993). Cognitive development. Englewood Cliffs, NJ: Prentice-Hall. 
Fuchs, L. S., Fuchs, D., \& Bishop, N. (1992). Instructional adaptation for students at risk. Journal of Educational Research, 86, 70-84.

Garcia, M. E., Schmitz, J. M., \& Doerfler, L. A. (1990). A finegrained analysis of the role of self-efficacy in self-initiated attempts to quit smoking. Journal of Consulting and Clinical Psychology, 58, 317-322.

Hoy, W. K. (2000). Changes in teacher efficacy during the early years of teaching. Paper presented at the annual meeting of the American Educational Research Association, New Orleans, LA. Session 43:22.

Hoy, W. K. \& Woolfolk, A. E. (1990). Socialization of student teachers. American Educational Research Journal, 27, 279-300.

Hoy, W. K., \& Woolfolk, A. E. (1993). Teachers' sense of efficacy and the organizational health of schools. Elementary School Journal, 93, 356-372.

Kanfer, R., \& Ackerman, P. L. (1989). Motivation and cognitive abilities: An integrative/aptitude-treatment interaction approach to skill acquisition [Monograph]. Journal of Applied Psychology, 74, 657-690.

Keefe F.J., Lefebvre J.C., Maixner W., Salleyan Jr., \& Caldwell D.S. (1997). Self-efficacy for arthritis pain: Relationship to perception of thermal laboratory pain stimuli. Arthritis Care and Research, 10(3), 177-184.

Kruger, J., \& Dunning, D. (1999). Unskilled and unaware of it: How differences in recognizing one's own incompetence lead to in- 
flated self-assessments. Journal of Personality and Social Psychology, 77(6), 1121-1134.

Lee, C. (1984). Accuracy of efficacy and outcome expectations in predicting performance in a simulated assertiveness task. Cognitive Therapy and Research, 8, 37-48.

Manning, M. M., \& Wright, T. L. (1983). Self-efficacy expectancies, outcome expectancies, and the persistence of pain control in childbirth. Journal of Personality and Social Psychology, 45, 421-431.

Moe, K. O., \& Zeiss, A. M. (1982). Measuring self-efficacy expectations for social skills: A methodological inquiry. Cognitive Therapy and Research, 6, 191-205.

Moore, W., \& Esselman, M. (1992). Teacher efficacy, power, school climate and achievement: A desegregating district's experience. Paper presented at the Annual Meeting of the American Educational Research Association, San Francisco.

Motl R.W., Snook, E.M. (2008). Physical activity, self-efficacy and quality of life in multiple sclerosis. Annals of Behavioral Medicine, 14(1), 111-124. doi: 10.1080/13548500802241902.

Multon, K. D., Brown, S. D., \& Lent, R. W. (1991). Relation of selfefficacy beliefs to academic outcomes: A meta-analytic investigation. Journal of Counseling Psychology, 38, 30-38.

Pajares, F. (1996). Self-efficacy beliefs in academic settings. Review of Educational Research, 66, 543-578. 
Pintrich, P. R., \& Schunk, D. H. (1995). Motivation in education: Theory, research, and applications. Englewood Cliffs, NJ: Prentice Hall.

Schneider, W. (2008). The development of metacognitive knowledge in children and adolescents: Major Trends and Implications for Education. Mind, Brain and Education, 2(3), 114-121. doi: 10.1111/j.1751-228X.2008.00041.X

Schraw, G., \& Dennison, R. S. (1994). Assessing metacognitive awareness. Contemporary Educational Psychology, 19, 460475.

Tschannen-Moran, M., \& Woolfolk Hoy, A. (2001). Teacher efficacy: Capturing an elusive construct. Teaching and Teacher Education, 17, 783-805. doi: 10.1016/S0742-051X(01)00036-1.

Woolfolk, A. E., Rosoff, B., \& Hoy, W. K. (1990). Teachers' sense of efficacy and their beliefs about managing students. Teaching and Teacher Education, 6, 137-148.

Yip, M. C. W., \& Chung, O. L. L. (2005). Relationship of study strategies and academic performance in different learning phases of higher education in Hong Kong. Educational Research and Evaluation, 11(1), 61-70. doi: 10.1080/13803610500110414. 